Journal of Southeast Asian

\title{
East Meets West: The Adaptation of Vietnamese International Students to California Community Colleges
}

Tam Huu Do

Irvine Valley College, nhattram831@yahoo.com

Follow this and additional works at: https://docs.lib.purdue.edu/jsaaea

\section{Recommended Citation}

Huu Do, Tam (2007) "East Meets West: The Adaptation of Vietnamese International Students to California Community Colleges," Journal of Southeast Asian American Education and Advancement: Vol. 2 : Iss. 1, Article 1.

DOI: $10.7771 / 2153-8999.1083$

Available at: https://docs.lib.purdue.edu/jsaaea/vol2/iss1/1

This document has been made available through Purdue e-Pubs, a service of the Purdue University Libraries. Please contact epubs@purdue.edu for additional information.

This is an Open Access journal. This means that it uses a funding model that does not charge readers or their institutions for access. Readers may freely read, download, copy, distribute, print, search, or link to the full texts of articles. This journal is covered under the CC BY-NC-ND license. 


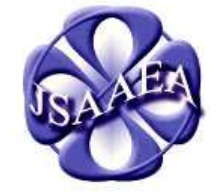

Volume 2

\section{Journal of Southeast Asian American \\ Education \& Advancement}

WWW.JSAAEA.org
A peer-reviewed

scholarly journal

published by the

National Association

for the Education \&

Advancement of

Cambodian, Laotian, and Vietnamese

Americans (NAFEA)

\title{
East Meets West: \\ The Adaptation of Vietnamese International Students to California Community Colleges
}

\author{
Tam Do \\ Irvine Valley College
}

\begin{abstract}
This study explores seven adaptation aspects that include language and communication, cultural awareness, loneliness and isolation, new educational settings, financial concerns, gender-based differences, and the political impact of the anti-communist Vietnamese American community. Based on Person/Environment Interactionism theory, case studies of eight students from Vietnam at two Southern California community colleges are considered utilizing data derived from weekly diaries, individual interviews, a final group meeting, and academic records. The students' prior assumptions and expectations are identified and their coping strategies to various adaptation issues are documented and analyzed. The ethnic diversity of Orange County generally facilitated the students' adaptation efforts in the aspects of language and communications, cultural awareness, and loneliness and isolation. The students seemed to readily adapt to the new educational settings and excel academically despite some different educational practices. There were no apparent gender-based differences in the students' adaptation. However, unwelcoming attitudes from the anti-communist members of the Vietnamese American community adversely impacted the international students' socialization with Vietnamese Americans, but did not impact their academic performance.
\end{abstract}

The recent influx of Vietnamese international students to American higher education is a new development that started in the mid 1990s. More than half of a century ago, in the 1950s, there were over 200 international students from South Vietnam in the United States and that number grew to more than 3,000 in the 1960s (Pham, 2002). However, for 20 years since the war ended in 1975 uniting North and South Vietnam, there was no educational exchange between Vietnam and the United States.

Since the early 1990s, a few years after this communist nation opened to the world with its đổi mới ("renovation") policy, Vietnamese students have begun to look for the quality, prestige, and credibility associated with a Western degree (Ashwill, 2001). Beginning in 1994, when President Clinton lifted the trade embargo and re-established diplomatic relations with Vietnam, the number of Vietnamese students in the United States jumped from 1,210 in 1997 to 2,266 in 1999 (Ashwill, 2001). After Clinton's visit to Vietnam in November 2000, there was another $25 \%$ increase (NAFSA, 2002). The

\section{(a)}

SOMERIGHISRESERVEDReaders are free to copy, display, and distribute this article, as long as the work is attributed to the author(s) and the Journal of Southeast Asian American Education \& Advancement, it is distributed for non-commercial purposes only, and no alteration or transformation is made in the work. More details of this Creative Commons license are available at http://creativecommons.org/licenses/by-ncnd/3.0/. All other uses must be approved by the author(s) or JSAAEA. 
latest available figure indicated that in 2005, 3,165 Vietnamese international students were enrolled in higher education in the United States (Foreign students' countries of origin, 2005).

Although Vietnam is the country with the greatest percentage of increase of international students to the United States in 2005-2006, the adaptation of its students has not been studied carefully and extensively like that of students from other Asian countries. There were a few studies related to pre-1975 students from Vietnam such as that of Pham (2002) however, those subjects were different from the current students from post-war Vietnam. Besides the differences in their educational background, to be elaborated later, the pre-1975 students were mostly non- or anti-communists who received close support from a small and cohesive Vietnamese American community that mostly shared their political view. There were anti-Vietnam War sentiments and activities among a small number of students but the conflict between them and the Vietnamese American community at the time was not consequential and its intensity, if any, was insignificant. In contrast, current international students from Vietnam were born and raised entirely in a communist society and are generally thought of belonging to the Vietnamese political or economic elite in order to be allowed to study in the United States. The current Vietnamese American community, meanwhile, has also changed drastically since 1975 to a congregation of former refugees who have become the most passionate critics of the present communist regime.

The presence of international students has been a special challenge for two-year colleges which traditionally direct and emphasize their service in response to local needs, and research on this issue is a relatively recent development (Wu, 1993). In 1988, the American Association of Community and Junior Colleges (AACJC) included for the first time in its mission statement the commitment to meet the cultural needs of the United States in an increasingly international environment and to focus on "global citizenship." With that growing emphasis, the number of international students at two-year institutions has begun to increase. Even before the events of 9/11/2001, the impact of international student population growth was felt most clearly in two-year colleges.

This study looks at the adaptation of Vietnamese international students in the United States by identifying their needs and concerns, analyzing the perceived cultural incongruity of the American higher education institutions, and discovering and examining the students' coping strategies to this new environment. Through a relational analysis of several factors uniquely connected to the Vietnamese international students, this study also examines their adjustment to life in the United States in general. This case study is based on Person/Environment Interactionism theory (Paul, 1980) which provides the basis to examine the interaction and the degree of congruence between the Vietnamese international students, their needs, and the college environment. The analyses of the coping strategies are enhanced contextually by the inclusion of past historical experiences and current political realities that seem to affect the students' adaptation process.

The topics of study include: The students' principal expectations and assumptions before their arrival to the United States; the basis on which these expectations and assumptions were formed; the ways these students reconcile their specific needs and concerns with the perceived cultural incongruity of the American higher education environment; the ways they prepare for and adjust to common adaptation issues; the 
gender-based differences, if any, and their implications on the adaptation process; and any impact on the adaptation that is caused by the lingering political conflicts between the Vietnamese American community and the present Vietnam.

\section{Background Information}

The following is a brief overview of the past and current developments of the Vietnamese educational system and a discussion of the characteristics of the present Vietnamese American community. These two factors are essential as they impact the manner in which Vietnamese International students adapt to the college environment and life in the United States in general. The degree of the adaptation success of these students depends largely upon the combination of their prior social capital, academic background, and the interaction they have with the Vietnamese American community.

\section{Vietnamese Educational System}

In ancient times, education in Vietnam included the transmission of cultural values through family and community living. These values were in turn, enriched by the formal teachings of its dominant religions such as Buddhism, Hinduism, Islam, Taoism, Confucianism, and Animism (Duong, 2002). For almost a thousand years afterwards, Vietnam fell under the cultural and military domination of China. China, however, began to sink into intellectual stagnation in the $16^{\text {th }}$ and $17^{\text {th }}$ centuries. During this decline, the creativity and original spirit of Chinese classical education was lost, and its narrow curriculum was far removed from the pressing problems and changing needs of the $19^{\text {th }}$ century (Education in Asian Civilizations, 2003). In the big picture, the decline of China paralleled its growing loss of domination in politics, economy, culture, and military over Vietnam and other Southeast Asian countries.

Meanwhile, in its campaign to colonize Vietnam in the $19^{\text {th }}$ century, the French were equipped with advanced technology and military; a strong drive to spread their gospel in the land traditionally imbued with Taoism, Confucianism, and Buddhism; and an unhidden agenda to exploit raw materials to satisfy the needs of its nascent and fast growing industrial revolution. In that context, the French colonial government politicized Vietnam's educational system to further its colonization goal. The French made every effort to abolish the old Chinese model and replace it with Western-style education. However, this was offered only to a limited number of privileged Vietnamese in order to form a class of low-level functionaries who would serve as an administrative bridge to connect the colonial government above and the mass below. The great majority of the people were denied a meaningful and significant education. Efforts were thus limited to mainly establishing elementary schools with solely the first three grades of primary education. Even then, only three percent of the population attended those schools (Pham, 1998). This approach helped the French to oppress and dominate the Vietnamese more effectively (Do, 1986). Most destructive to Vietnam's cultural heritage, the French severed the Vietnamese's tie to the past by replacing the traditional written language with the Romanized form of Vietnamese writing. The latter was invented by Catholic priests for the sole purpose of facilitating their relentless mission to spread the gospel and convert the Vietnamese to Christianity (Nguyen, 1998). The more familiar Chinese 
characters, Hán, and the Vietnamese's own writing system, Nôm, were forcefully abandoned and eventually faded from the realm of education.

Recently, education in North Vietnam has been profoundly influenced by Eastern European models while South Vietnam has mostly followed the French model and, during the last ten years of the war, the American model. After the country's reunification following the war, the government imposed an educational system based entirely on that of North Vietnam (Pham, 1998). At present, however one can find growing influences of several educational models as more and more scholars, foreign and Vietnamese, apply what they learn in different countries with markedly dissimilar systems and philosophies of education, thus adding more dimensions and more directions to an already muddled system.

In trying to regulate the influx of various ideas and allowing the indigenous system to gradually adjust to new educational practices, Vietnam's Ministry of Education and Training (MOET) has attempted several reforms (Borton, 2002). Nevertheless, the need for quality education has remained large and growing. Since the early 1990s there has been an explosion of demand that neither the state sector nor the more recently established private institutions can realistically hope to meet. In 2001, the number of students represented a near six-fold increase over the figure in 1990. In 2002, more than 900,000 Vietnamese were enrolled in colleges and universities while those sitting for tertiary entrance exams numbered 1.2 million (Borton, 2002). Furthermore, as it attempts to reform itself to adapt to the nation's unsteady social transformations and hasty economic development, Vietnam's educational system is undergoing a chaotic transitional period. The result is a deeply troubled higher education system which is plagued by low faculty salaries, crumbling infrastructure, overcrowding, outdated curriculum and training, and mixed results in efforts to produce quality graduates.

\section{Vietnamese Immigrant Community in the United States}

After the victory of North Vietnam in 1975 to reunite the divided and war-torn nation, several waves of refugees left South Vietnam and many were admitted to the United States. This exodus slowed to a trickle in the recent decades and ended as Vietnam became more economically stable and more politically open with its so-called "free market" economy policy. Thirty years after the war, there were about 2 million former Vietnamese refugees living outside of Vietnam (Igasaki \& Niedzwiecki, 2004).

Orange County in Southern California has become the area with the highest concentration of Vietnamese outside of Vietnam (Igasaki \& Niedzwiecki, 2004). In general, Vietnamese Americans have adapted quite successfully in their new country. However, from the beginning, one of the defining characters that brought attention to the Vietnamese American community has been its infatuation with politics. This is evident in the passionate opposition of the older generations to the current government of Vietnam (Martelle \& Tran, 2000). This anti-communist sentiment was kept alive by a small but steady influx of new immigrants who were allowed to leave for the United States under humanitarian and family reunion guidelines agreed to by both governments.

Some Vietnamese American community members consider the international Vietnamese students as likely belonging to the elite class of high ranking communist cadres or well-to-do business people due to their ability to obtain the permission for 
overseas studies and to afford such expenses. These international Vietnamese students thus find themselves in a uniquely unfavorable relationship with the Vietnamese American community. In many instances, they even refrain from revealing their identity to avoid any problems with the community's anti-communist members.

\section{Methodology}

This case study focuses on eight Vietnamese international students who attend two community colleges in Orange County, California. Employing a multiple method approach that includes a set of diaries, in-depth interviews, and discussions in a group meeting, the author collected the information, put the students' personal experiences into various and distinct adaptation categories, identified their prior assumptions and expectations, and analyzed their coping behaviors and activities over a period of a semester.

Data were coded, categorized, and analyzed to identify coping behaviors and to examine adaptation patterns of each participant. The transcripts documenting the students' academic performance and the pattern of collegiate courses taken both in Vietnam and in the United States were added to the other sources for triangulation purposes in order to obtain a more complete description of the students' adaptation process.

\section{Sites}

College A is a public, two-year post secondary institution that was founded in the late 1940s. As the larger campus of a multi-campus district, College A is located in a well established city in Orange County and has about 35,000 students, including an estimated 1,000 international students from 75 countries. It is attended by about 20 international students from Vietnam in addition to a large number of Vietnamese American students.

College B is located in South Orange County and was founded in the mid-1970s. It is the younger of the two colleges in the district and is currently attended by about 12,000 students, of whom 400 are international students from 46 countries. Only five of the international students are from Vietnam.

\section{Participants}

During the 2004-2005 academic year, the combined number of Vietnamese international students that attended College A and College B totaled about 25. However, about half of these students were unavailable during the Spring 2005 semester due to either transferring to other universities or returning back to Vietnam. Eight of the remaining students agreed to participate in the study. There is always an element of self-selection in an interview study because participants must consent to be interviewed (Seidman, 1998), however this factor did not substantially impact the study's results. 
Table 1

Participants

\begin{tabular}{llccccc} 
Name $^{\text {a }}$ & Gender & Age & Site & $\begin{array}{c}\text { Began learning } \\
\text { English }\end{array}$ & Time in the U.S. & $\begin{array}{c}\text { TOEFL } \\
\text { Score }\end{array}$ \\
\hline Dung & Female & 19 & College A & $1^{\text {st }}$ grade & 1 year 8 months & 537 \\
Minh & Male & 21 & College B & $6^{\text {th }}$ grade & 1 year 5 months & 537 \\
Ngọc & Female & 21 & College A & $5^{\text {th }}$ grade & 9 months & 506 \\
Nhu & Female & 21 & College A & $6^{\text {th }}$ grade & 3 years 4 months & 557 \\
Thu & Female & 21 & College A & $6^{\text {th }}$ grade & 2 years 4 months & 660 \\
Thuận & Male & 20 & College A & $6^{\text {th }}$ grade & 1 year 8 months & 527 \\
Tuyết & Female & 24 & College B & Junior High & 2 years 8 months & 480 \\
Uyễn & Female & 20 & College A & $5^{\text {th }}$ grade & 9 months & 543 \\
\hline
\end{tabular}

${ }^{\mathrm{a}}$ Pseudo-names as chosen by students themselves

${ }^{\mathrm{b}}$ TOEFL: Test of English as a Foreign Language

One of these eight Vietnamese international students, Tuyết, came from Japan. She was born in a refugee camp in the Philippines after her parents escaped from Vietnam. When she was three months old, her family was allowed to immigrate to Japan. They still retain their Vietnamese citizenship and are currently identified by Japanese authority as Vietnamese immigrants. Tuyết's parents have taught her Vietnamese and spoke to her mostly in Vietnamese at home. She spent her senior year almost entirely with her relatives in Vietnam. She understands the language very well but does not speak as fluently as the other students. She preferred to communicate with the author in English.

\section{Sources of Data}

\section{Diaries}

As diaries provide rich descriptions of how people think about their world (Bogdan \& Biklen, 1998), in this study, the content was analyzed and provided additional basis for subsequent efforts to collect further information. Via e-mail, each student submitted a one- to two-page diary every week during the length of the study. Students were also instructed not to share their diaries with each other.

The adaptation themes to be discussed in the diaries were summarized from the literature review which included: language and communication; cultural awareness, loneliness and isolation, new educational environment, financial issues, and gender-based issues. Impacts of potential conflict were added due to the sensitive relationship between international Vietnamese students and the Vietnamese American community. The diaries described events related to these seven specified themes and the ways these students reacted to those events as part of their adaptation/coping experiences. Guiding questions were provided to the participants to help them focus on these themes which were adapted from a variety of sources such as the ten-step Ecomapping Model of the Person/Environment Interactionism theory (Huebner \& Corazzini, 1978), the International Student Questionnaire (Wilson, 1996), and the Michigan International Student Problem Inventory (Porter, 1962, 1977). 


\section{Individual Interviews}

Seidman (1998) explains that at the root of in-depth interviewing is an interest in understanding other people's experience and the meaning they make of that experience. Additionally, interviewing provides access to the context of people's behavior and thereby provides a way to understand the meaning of that behavior. Two semi-structured, in-depth interviews were scheduled with each participant during the study period. While some of the questions were designed in advance and appeared consistently from one interview to the next, others varied from student to student depending on the different content of the individual diaries. All interviews were conducted in Vietnamese except for with Tuyết (who came from Japan) and in this case both Vietnamese and English were used. The set of first interviews were two hours long and were designed to find out the biographic information of the students and to explore their prior assumptions and expectations. It also allowed the opportunity to review the emerging trends of the diary's content and to clarify any ambiguous data collected up to that point. The subsequent onehour interviews explored additional adaptation themes and clarified any vague portions of the subsequent diaries.

\section{Final Group Discussion}

A two-hour final group meeting was designed to provide a forum where the students could eventually share their adaptation experiences with each other. Besides the purpose of identifying any missing information and clarifying data that remained ambiguous, the particular aim of this meeting was to afford the students the opportunity to further articulate their adaptation process through the discussion of their experiences in a group setting. Excerpts from the diaries were used to form the basis of about forty thematic questions that guided the discussion. Students seemed to discover additional meaning in their coping behaviors and adaptation experiences by listening to and reflecting on various responses from their peers to the same adaptation issues.

\section{Academic Records}

As part of the research documents, the students' academic records were collected along with their personal diaries. Students were asked to share both their American and Vietnamese college academic transcripts that show the type and pattern of courses enrolled and their resulting grades. These records were placed together with the transcribed interview materials and the diaries to provide a more complete picture of the students' adaptation process.

\section{Data Analysis}

In case studies, Miles and Huberman (1994) recommend conducting early analysis. Creswell (1998) also suggests that analytic procedures may evolve as the research process unfolds. It is the intent of the researcher to analyze the content of the first set of interviews to prepare for the subsequent round of interviews and to appropriately formulate the questions used in the final group meeting. Bogden and Biklen (1998) 
similarly emphasize that, as the events are allowed to unfold naturally, the data collection and analysis strategies depend upon and evolve with what and how the subjects react.

Yin (2003) suggests that the analytical process must be well controlled so that the data presented in the final case study report must be assuredly the same as the data during the collection process. In addition, depending on the information collected from each student regarding his or her unique situation and adaptation experience, the author used all four forms of data analysis and interpretation in case study research as proposed by Stake (1995): categorical aggregation, direct interpretation, establishment of patterns, and naturalistic generalizations. Similarly, a collection of excerpts of similar responses to an adaptation issue helped reveal the "patterns" of adaptation behaviors. The author also searched for connecting threads and patterns among the excerpts.

The academic transcripts from Vietnam provided a sort of baseline against which their American college transcripts were assessed in terms of the students' current academic performance and pattern of courses taken. This comparison added the educational dimension necessary in evaluating the adaptation process of the students.

\section{Impact of the Researcher}

The interaction between the researcher and the participants is inherent in the nature of interviewing and might have an unintending effect on the participating students (Seidman, 1998). Measures were thus implemented to ensure an acceptable degree of trustworthiness and credibility. As counselor and counselees, the relationship between the researcher and some of the participants was by default unusual in that it was established prior to this study. Direct contacts with the students were designed to take place at "neutral" places (such as the cafeteria or student lounge), away from the researcher's counseling office where an appearance of coerciveness may be misconstrued. The prolonged and close engagement between the researcher and the students over the research period lessened the initial skepticism and allowed the trust and the understanding between them to eventually grow.

The researcher's personal background shapes his own attitude and biases. Being forced to leave his native country as a young Vietnamese refugee, he was understandably fervently anti-communist. However, as he gradually became more mature, educated, and knowledgeable of the background of the Vietnam War, he developed a more balanced view of the contemporary history of Vietnam. Most recently, his disillusion with certain aspects of the Western civilization generated in him the desire and the determination to return to the culture of his birth nation and embrace the values inherent in his heritage. Thus, to minimize any innate biases the researcher might have had regarding the Vietnamese students' adaptation process, the formulation of thematic questions was based on previously used instruments. Even though variations existed between unique situations of individual students, the researcher had attempted to retain a degree of uniformity in all the interviews by consistently referring back to these thematic questions.

The procedure of "member checks" was also regularly and rigorously conducted with the participants to validate the accuracy of narratives collected and assumptions made during the interviews, the document analysis, and the analysis of the diaries. The large and enriching amount of data collected from this multiple method approach enabled the inclusion of various assessments for triangulation purposes. This multiple approach 
allows the avoidance of the questionable practice where the researcher tried to force the excerpts of data into categories, and categories into themes that he already had in mind, rather than let them develop from the experience of the participating students (Seidman, 1998).

\section{Findings and Analysis}

\section{Student Background}

To fully appreciate the students' experiences and their adaptation strategies, certain circumstances of historical significance unique to Vietnam must first be examined and clarified. During the war, Vietnamese families typically suffered the tragic situation in which their individual members chose opposing political orientations and joined rival forces, communist versus "nationalist." While some did so by choice, others were forced. The result was heartbreaking confrontations in the battlefield where family members often killed each other. The pain was deep, the memory was unforgettable, and the conflict was kept alive in literature and in countless popular songs and stories. Time has helped the healing process but thirty years might not be long enough and, underneath the normalcy and business of daily life, the unspoken tension, however subtle, remains palpable to a certain degree. In this context, when the husband and the wife come from opposing backgrounds, political discord often exists among their extended family members. Reactions range from mild and indirect remarks to serious and outright provocations. Half of the Vietnamese international students in this study have parents from both North and South Vietnam with extended families belonging to both sides of the conflict (see Table 2). Some even have anti-communist relatives living in the United States.

Second, the students' religious background adds another dimension to their adaptation process (see Table 2). For a long time, Vietnam's main religions have been Buddhism, Taoism, and Confucianism as their philosophies and practices agree harmoniously with the Vietnamese tradition of ancestor worship. Then, beginning in the mid $19^{\text {th }}$ century, profound and irreversible changes to the course of Vietnamese contemporary history occurred when colonialism and Catholicism came hand in hand from the West, following each other's campaign and riding each other's conquest. During the colonial war, the Vietnamese who practiced Catholicism have generally been viewed as collaborators with the French against Vietnam. The political and philosophical conflicts between Vietnamese Buddhists and Catholics remain today both overseas and, to an apparently lesser degree, in Vietnam. While the majority of these students identify themselves as Buddhists, the current environment in the United States is predominantly Christian. Many of the international students' relatives in the United States were Christian, thus leading to further tensions in their adaption. 
Table 2

Parents' Place of Birth, Religion, and Return Visits to Family in Vietnam

\begin{tabular}{|c|c|c|c|c|}
\hline \multirow{2}{*}{ Name } & \multicolumn{2}{|c|}{ Place of Birth } & \multirow{2}{*}{$\begin{array}{c}\text { Student's } \\
\text { Religion }\end{array}$} & \multirow{2}{*}{$\begin{array}{c}\text { Return Visits } \\
\text { to Family }\end{array}$} \\
\hline & Father & Mother & & \\
\hline Dung & North & North & Buddhist & 1 time \\
\hline Minh & North & South & Buddhist & 1 time \\
\hline Ngọc & South & North & Buddhist & Not yet \\
\hline Nhu & South & South & Buddhist & 3 times \\
\hline Thu & North & North & Buddhist & Not yet \\
\hline Thuận & South & North & Buddhist & 1 time \\
\hline Tuyết & South & South & Catholic & Not yet \\
\hline Uyễn & North & South & Buddhist & Not yet \\
\hline
\end{tabular}

The eight Vietnamese international students seemed to share several similar characteristics. First, all of them consider their family as middle or even upper middle class. Second, almost all of them started learning English very early, since fifth or sixth grade and some began even earlier (see Table 1). Many of them were good to outstanding high school students and received high placements in their English and Math college assessment tests indicating an academic readiness for college. Third, several of them have relatives or families in the United States but most do not stay in close contact with them for many reasons, among them the political and religious conflicts with some of their relatives. And fourth, even with their parents' (and grandparents') diverse background, most of them are Buddhist (see Table 2).

Several differences were also found among the background of the participants. Even though their parents are all affluent, they occupy different professions. Most are business people, some are professionals such as physicians, and only a few are state employees. Some of these students have already obtained some post secondary education in Vietnam either through public universities or semi-private, foreign-operated institutions. Prior to coming to the United States, a few had already traveled outside of Vietnam, though mostly in Asia. Their length of time in the United States varies greatly, from nine months to more than three years indicating a wide range of experiences with and reactions to the American environment (see Table 1). Even though they all started learning English at an early age their Test of English as a Foreign Language (TOEFL) scores vary widely (see Table 1). Their fields of interest are also very diverse, from Business Administration to Chemical Engineering, from Human Resources to Pharmacology. The students also differ in their desires to continue to graduate studies or return to Vietnam. About half of them have parents from geopolitically different regions of Vietnam. And finally, about half of them have returned to Vietnam since coming to the United States to visit their family (see Table 2). 


\section{Adaptation Issues}

\section{Cultural Incongruities}

The Vietnamese international students in this study acknowledge the differences and significant incompatibility between Vietnamese and American cultures. This poses great challenges to their adaptation process. Dung expressed in her diary:

So many contrasts between the two cultures. Sometimes we don't know what is right or wrong, what should be done or shouldn't. Vietnamese culture emphasizes more in the whole, the conformity is sometimes very stressful, while the US values are more about individuality.

Their initial optimistic impressions of the United States and their appreciation of some positive aspects of the American culture, such as assertiveness and kindness, have been mixed with the realization that several of their prior assumptions were not accurate. Some of the cultural issues that were discussed include the fast pace of life, the straightforward verbal expression, and the peer pressure to reject one's cultural identity; the practice of showing affection in public is particularly difficult for them. Most notable are their unsuccessful socialization with Americans, even with Vietnamese Americans. Thu commented:

I was so isolated in school, feeling like an alien, having nothing in common with other American students; our conversation usually did not last more than five minutes. "Hi, how are you doing?..." and then they would be talking about something I did not even know or had no interest in knowing. I guess it made me even more different from other students.

Eventually, similar to some other groups of immigrants, they have to resort to the strategy of establishing relationships with people who share a congruent cultural background. In addition, several of these students become frustrated with having to confront the overt efforts to convert their religion from Buddhism to Christianity by Americans, who remain unreceptive to religions other than Christianity, and even by the students' own Catholic relatives who live in the United States. Dung said in her first interview:

Mà bên kia (West Virginia) cũng có nhiều thành kiến lắm... Người Mỹ hỏi em là ở Việt Nam em có theo đạo nào không? Họ rũ về nhà và giải thích đạo thò Thiên Chúa là văn minh làm nhu em mới ở trên núi xuống, không biết gì hết.

In West Virginia, there are also much prejudices... The Americans asked me what religion I belonged to in Vietnam. They took me home and tried to explain to me that Christianity is something civilized. [They consider me as uncivilized] knowing nothing like I just came down from the mountain. 
Minh told of his experience, "I know America bao gồm nhiều [includes many] background and religions. America is still a Christian country. I met a lot of people here try to $d u$ vào [convert me to] Christian. It shocked me. Too much!"”

It seems the majority of these students have decided to give up the difficult task of exploring and joining the prevailing culture. Shortly after their arrival, and when the initial enthusiasm had started to fade away, they preferred to stay outside of the mainstream and maintain minimal interaction with Americans and Vietnamese Americans. They developed and relied on their own network which included other foreigners.

\section{Language and Communication}

Several researchers (Dalili, 1982a; Feng, 1991; Sun \& Chen, 1997) cited language and communication as some of the main obstacles facing international students who must demonstrate an acceptable level of English proficiency in order to attend higher education in the United States. These eight Vietnamese international students have all taken the TOEFL exam to meet the college entrance requirements. College A requires a minimum score of 500 and College B requires a minimum score of 470 . The students' adaptation experiences in relation to issues of language and communications are abundant with similarities and diversities.

Even though the majority of them started learning English in their primary grades, and more extensively later on, their verbal skills are nonetheless markedly deficient. The explanation of that paradox seems to be the heavy emphasis on grammar and not on comprehension or other oral skills such as pronunciation, listening, and speaking in previous English learning. The lack of both English-speaking teachers in Vietnam and the opportunities to practice their oral skills results in a low level of oral English proficiency which in turn causes the students frustration because it denies them an essential communication tool. It took several of them a few months to more than a year to attain adequate comprehension and conversation skills. Dung explained in her diary:

Studying English in Vietnam helps me in writing in correct grammar but not much in speaking. To some people, it even becomes a barrier for speaking because they are afraid of making mistakes... It's always better if you speak correctly, especially for people in business major like me.

Thuận shared his experience:

[Phần soạn sũa Anh văn] không giúp gì được. Phần grammar thì mình good tại vì học theo hệ thống của Việt Nam là tập trung vô grammar. Trong khoãng chùng nũa năm sau khi đến Mỹ em không hiểu gì cả. Sau nũa năm thì em có thể nói được nhung tại vì mình quen với lối sống im lặng rồi nên không liên hệ nhiều. Hồi mói qua em cũng nghe TV/radio nhưng không hiểu.

[The preparation for English] did not help. The grammar part is good because the Vietnamese system focused on the grammar. During the six months since my arrival, I did not understand anything. After that time I was able to communicate 
but I was used to a quiet lifestyle and did not interact a lot. When I first arrived I tried to listen to TV and radio but failed to understand.

Contrary to findings that language ability is related to academic success (Eid \& Jordan-Domschot, 1989) and the extent of English usage outside and inside the classroom strongly correlates with the level of academic achievement in language and academic subject matter (Ellis, 1993), many of the participants reported not having academic difficulties. It seems the sole emphasis on grammar and the lack of focus on verbal English learning such as listening, speaking, pronunciation, and reading do not significantly affect these students' academic performance in general, or their English courses in particular. This is similar to other studies with international students in which they acquire academic English in order to function successfully in their classroom despite having little acquaintance with the language used in social situations (Lacina, 2002). Based on their academic transcripts, the majority of these students received the grade A in their English courses; including English as a Second Language, Freshman Composition, and/or Critical Thinking. The high scores in their English classes can be seen as the Vietnamese international students' most direct adaptation strategy against their lack of English proficiency. Through sheer hard work, they study to improve their English.

It is well established that mastering the English language is the primary factor in facilitating the adaptation process of international students in the United States. However, in addition to the verbal language, communication skills that involve the way a message is delivered and received and how its culturally sensitive content is treated, also plays a critical role in the students' effort to adapt to this new environment. Like any other ethnic group, Americans' subtle and unique patterns of communication are often confusing to foreigners. To American students, statements such as "I'll call you soon" or "Let's get together" are just a polite way of ending a conversation; miscommunication often results when the international student interprets the statements literally (Lacina, 2002). Nhu elaborated in her diary how she views the American greetings:

Two years ago, I think how nice is American, they always seem to be nice with everybody. They say hi, hello to each other, end of conversation, they say nice to meet you, or it's nice to talk with you, or have a nice day. To them [Americans], it is like a habit, maybe they don't mean it when they say it but they say it anyway. A conversation seems to be not complete without things like that. That's why I don't feel like to say it just because of that.

Zimmermann (1995) discovered that talking with American students was considered the single most important factor in improving the international students' language skills. Yet, from the perspectives of some of the participants, the matter is not that simple. The students' foreign accent makes them self-conscious and hesitant when starting a conversation with American classmates. Lacina (2002) maintained that, despite the long history of bilingualism in the United States, Americans still have no patience to listen to someone whose accent is different from their own. Many Americans remain fearful of other cultures or nationalities due to stereotypes they have of different groups. Furthermore, Yook (1995) found that Asian international students have at least three 
main handicaps in verbal expression, which include the language barrier, the fact that they come from a culture in which gesturing and speaking loudly are frowned upon, and the fact that they have no experience speaking publicly in their own countries.

Most Vietnamese students seem to experience certain difficulty when attempting to befriend Americans. A common reason is their lack of cultural currencies to understand the hidden meanings of the verbal language used by Americans in their communication. Therefore, even with an adequate level of English proficiency, communications remain a difficult issue. Several Vietnamese students resolve this issue by turning to people who face situations comparable to theirs. Knowing that they have to socialize to improve their English but dread the prospect of having to face certain cultural barriers in initiating a friendship with Americans, some become selective and careful in their search for someone with whom they can socialize and practice English. Sharing a sense of camaraderie with other non-English speakers (who are "like themselves"), the Vietnamese students feel comfortable and confident in verbally expressing themselves, though not necessarily in correct English. Dung wrote:

One thing I like about the intercultural club is that we made mistake when we speak all the time, and no one care about that. We help each other out with pronunciation... We never feel bad about being corrected by someone else. But if you just put me among all Americans, either they will get bored listening to us or we feel uncomfortable.

Thuận expressed his willingness to speak English to his non-English speaking friends in the intercultural club:

Đã lâu lắm rồi mới nói chuyện tiếng $N$ vui vẽ nhu vậy, mình cũng biết là mình thuộc hàng yếu tiếng $N$ nhất trong cái club đó nhung thật tình ngày hôm đó dẹp hết cái sĩ diện wa một bên, nói ko ai hiểu thì thôi, dù sao thì cũng ráng.

It has been a long while since I enjoyed speaking English that much. I realized that I was the worst one in speaking English in that club but, that day, I put away my pride. I did not care whether or not people understood me. I tried hard.

Different from immigrants who have to master the English language as much as they can, international students are usually only in the United States for only a short period of time for the purpose of achieving an educational goal (Lacina, 2002), and they will eventually leave the English language environment. International students tend not to return to their native country while immigrants stay and thus tend to be more receptive of the new culture's influences. The international Vietnamese students socialize to adapt but they do that mostly with non-English speaking groups to survive in a diverse community where English proficiency is certainly desirable but not mandatory. California's ethnic diversity and Orange County's large population of non-English speakers apparently facilitate these students' adaptation efforts as far as communication issues are concerned. 


\section{Loneliness and Isolation}

Coming to the United States and having to adjust to environmental, sociological, and psychological impacts that are abrupt, far-reaching, and substantial, international Asian students often experience periods of isolation and loneliness because of their inability to function in an English language environment that cuts them off from traditional support services (Fels, 1994). For the international Vietnamese students, the general feeling of loneliness was quite prevalent and was usually triggered by their homesickness. Nhu shared her feelings:

It has been three years but sometimes I still have this feeling. I felt lonely from inside out and outside in. Không có tiếng xe gắn máy, không có tiếng rao của cô bán xôi. [I missed the (familiar) sound of the motorbike, the shout of the sweet rice merchant]... I was lying on my bed, feeling something rolling on my cheeks, finding myself empty and unattached. What a depressing morning... I have talked a lot today, to many people, but it wasn't in Vietnamese.

The reasons for their isolation came from not only the language difficulty but also cultural incongruities.

Gribbons \& Dixon (2001) recommend an increase in socialization and networking activities as effective ways to support the integration of foreign students into the American society. However, many of the participants reported that it is difficult for them to make friends with their American classmates. One often cited reason is their accented English. The loneliness and isolation problems are so serious that they choose to use the Vietnamese language, at the risk of hindering their English acquisition, to socialize and remain in their network of supporting relatives and non-American friends. Minh reported during the interview:

Tưi Chinese nó cũng kiếm bạn Chinese. Nó nói thã̃ng là làm bạn nhu vậy thì nó cảm thấy safe, security... Em có nhiều người bạn không phải là Mỹ vì cùng cảnh $n g \hat{o}$.

Even the Chinese look for Chinese friends. They don't hesitate to say that such friends give them a sense of safety, of security... I have many non-American friends because they share similar situation.

This is congruent with Feng's (1991) findings that Asian international students, faced with adaptation obstacles due to the high degree of cultural incompatibility with Americans and, to a large part, to their perceived discrimination by the American classmates, tend to form their own community that isolates them even more from the host culture and further impacts their adjustment process. This phenomenon is also found in the 1.5 generation of Asian Americans (Kim, Brenner, Liang, \& Asay, 2003). Ngọc described her experience:

Có nhiều Mỹ trắng nó không thích Asian. Em họ thì em phải chung group với người ta. Nó nhái mình. Impolite. Nó nhái em mà nó nghĩ là em không hiểu. Tại 
Journal of Southeast Asian American Education and Advancement, Vol. 2 [2007], Iss. 1, Art. 1

Do - "East meets West"

nó không hiểu rồi nó hỏi bài em. Em đang giải thích bài thì nó quay qua nó nói với nhỏ bạn của nó rồi nó nhái em rồi nó cuời với nhau. Nó nghĩ là em không hiểu.

Many Caucasian Americans do not like Asians. I had to join a group during my study at the college. These students parodied my English in an impolite way. They thought I did not know. They did not understand the lecture and asked me to explain. While I was explaining, they turned to each other and parodied my English and laughed with each other. They thought I did not know.

Even when they are proficient in English, Asian international students often feel they do not share common topics and interests with Americans. Seemingly trivial yet telling examples of such disconnect and isolation include instances when Americans talk about football, baseball, and so on while Asian students know little of American sports; Americans tell jokes but few Asian students understand them (Feng, 1991). Uyễn expressed her feelings:

Người bạn Mỹ thì approach rất là dê̂. Người Mỹ em cảm thấy là ho cuñng rất là friendly. Nhưng mà quen thì dê̂ mà keep ho cũng khó là vì cái culture mà different thì rất khó tâm sụ nhù là đối với nhũng người Á Đông. Và em dễ làm quen với bạn gái [Mỹ] hơn. Ngay cả với nguời Việt Nam cũng vậy... em không sợ là khi mình nói người ta không hiểu nhưng chính sụ khác nhau giũa culture... Mà em cũng không biết phải diễn tả nhu thế nào nũa.

It is very easy to approach the Americans. I feel that Americans are very friendly. However, starting a friendship with them is easy but keeping them as friends is more difficult because the differences in culture make it hard to share things like with other Asians. And it is easier for me to make friends with the [American] females. Even with the Vietnamese [American]... I am not afraid they don't understand what I say but it is the differences in the cultures... I don't know how to express this.

Again, as with the issue of language and communications, several of the international Vietnamese students intend to return to Vietnam and, therefore, are not motivated to adapt fully. They only need to survive to complete their study before returning to their own cultural roots.

\section{New Educational Environment}

Several of the international Vietnamese students view the American educational system favorably. Some are impressed with the American system's superior physical environment in addition to the practicality and applicability that departs radically from the Vietnamese system. But these students also have to face new educational concepts and learning methods such as group study and classroom participation or student involvement where the lack of confidence in their English skills seems to be one of the 
main problems. Dung reported her apprehension of the practice of classroom participation:

One thing in classroom that is not familiar to me is the discussion. We did not have this kind of group discussion in Vietnam... Sometimes classroom participation point scares me because I am not the type of asking a lot of questions during the lecture... I would come and talk to the professor in the break with much more confidence than asking in class.

International students often feel overwhelmed initially by many aspects of university life such as academic programming, registration procedures, housing, and health services (Dalili, 1982b). Similar to some first-year American college students, but at a more significant level due to the language difficulty, Vietnamese international students initially have trouble understanding lectures, taking notes, answering questions, and writing essays. Contrary to the concern that the switch from the customary practice in Asia of rote learning to the American emphasis on individual exploration and expression may be difficult for Vietnamese international students (Stevens \& Philips, 1990), very few of them experienced any academic problems. It seems they compensate their lack of English proficiency by maximizing their cognitive skills, one of three suggested crosscultural adaptation skills (Bleichmar, 1998), to ensure their academic success. The students, however emphasized their astonishment about the differences in teacher and student behaviors. In Vietnam, when a teacher addresses the class, students are expected to sit quietly, take notes, and never challenge or contradict the teacher. In America, however, students are expected and even encouraged to ask questions and offer their own opinions. These observations tend to confirm previous findings about the passive participation so prevalent in Asian educational systems. Ngọc observed:

Điều khác biệt lớn mà tôi nhận ra khi đến Mỹ và họ ở đây là khoảng cách giữa thầy cô giáo và sinh viên không là quá lớn, khác hắn với sinh viên và thầy cô giáo $o$ ơ Việt Nam. Ho có thể nói chuyện, trao đổi thảo luận rất thoãi mái tụ nhiên trong lớp, và đôi khi còn rất thảng thắn nữa... Dường nhu không có sụ ngần ngai hay khoãng cách nào trong lóp học.

The greatest difference that I noticed when first attending the college here is the distance between teachers and students. This distance is not that huge. Teachers and students can talk to each other, exchange and discuss ideas comfortably with each other, and sometimes in a straight manner... There seems to be no hesitation and no distance in the classroom.

According to Siegel (1991), counselors can help international students make requisite adaptations to fulfill their educational and personal goals in the United States while holding on to their roots and sense of cultural integrity. However, Kinoshita \& Bowman (1998) warned that Asian students, in particular, are less likely to seek help for their emotional and interpersonal problems than their American counterparts due to culturally different help-seeking preferences. Lee and Mixson (1995) also found that 
Asians generally rated counseling as less helpful for personal-emotional concerns, and rated their counselors as less competent than did the Caucasians.

Counseling is an educational novelty to several Vietnamese students who prefer to not utilize that service for their emotional problems and only use it moderately for their academic issues. Ngọc wrote,

Có bao giờ tôi phải hẹn gặp với một counselor để làm educational plan hay xin ý kiến, lời khuyên gì trước đây đâu. Orientation cũng là một khái niệm xa lạ.

Previously, I have never had to make an appointment to see a counselor for an educational plan, an opinion, or an advice. Even orientation is an alienated concept to me.

Friends were their most preferred source of help, followed by their parents and teachers. This is similar to the report that a noticeable portion of the 1.5 generation of Asian Americans expressed negative attitudes toward seeking help from psychologists or counselors (Kim, Brenner, Liang, \& Asay, 2003).

\section{Financial Difficulties}

Being financially self-supported, a common concern among the international Vietnamese students is the limitation of their financial resources. Not only does the American higher standard of living create financial troubles to these students, its different currency rates from that of Vietnam also confuse the way they manage their expenditures, at least in the beginning. This is congruent with the findings that foreign students are most concerned with financial issues (Barakat, 1988). Thuận shared his feelings:

Vì currency của Mỹ cao hơn VN nên việc tiêu tiền của tôi ở đây cũng phải tiết kiệm và suy nghĩ kĩ lắm. Tiền Ba mẹ gỡi tù VN sang thiệt sụ là không "thấm thía" gì với nhũung gì tôi cần phải tiêu (dù đã cố gắng tiết kiệm, không tiêu xài phung phí rồi)... Tôi không được làm việc ở đâu ngoài truờng học... Đặc biệt là không được làm quá 20 tiếng mối tuần. Khó khăn thật!

Due to the higher rate of the US dollar I have to be very frugal and careful in my expenses here in the US. The amount of money my parents send me really means nothing compared with what I need (although I already tried to be penny-wise, not to be wasteful)... I am not legally allowed to be employed off campus... Specifically, I can not work more than 20 hours per week. It is very difficult!

Since 2001, coping with the drastic increase in tuition even at the two-year institutions, international students at some colleges have scrambled to meet the once-neglected criteria that allow them to work on-campus. They then have to compete with the employment eligible native students for on-campus employment that is already on short supply.

Several Vietnamese students deal with their financial problems by shortening their stay in the United States. They change their initial, more ambitious academic goals 
such as transferring to a four-year university for a bachelor's degree, to the much shorter goal of completing only a two-year associate degree to qualify in the shortest amount of time for the "practical training" option. This allows them to work legally, with a student visa, in the United States. For students who are too close to their goal to afford the change of plan, they struggle to increase the number of units enrolled per semester to finish their study as soon as possible. This high-unit approach, however, tends to reduce their chance of maintaining a good grade point average and inevitably adds to the stress that already overwhelms them.

Unlike in the United States, many students in Vietnam do not work, thus they expressed appreciation of their parents' sacrifice to support their education abroad. While some become stressed by their family's unreasonable expectation of their ability to be financially self-sufficient, others develop higher self-esteem when forced to be employed, recognizing their ability and the opportunity to contribute to their own education. It is interesting to note that the majority of the students do not want to burden their Vietnamese American relatives with their financial needs.

\section{Gender-Based Issues}

Most female international students come to the United States because their aspirations had reached a level that could not be satisfied by local opportunities. The problems they encountered are, in general, somewhat similar to those facing the male international students, such as lack of English proficiency, discrimination, and Americans' lack of knowledge about other cultures and countries (Fatima, 2001). While the majority of the international Vietnamese students believe the ways to cope with homesickness are independent of one's gender, some express their observation that female students, due to their ability to easily make friends, have more advantages than male students in using socialization as a coping mechanism against loneliness and isolation. Thuận expressed his view on the ability of female students in the socialization process:

Hình nhu con gái dễ kiếm bạn hơn. 2 đưa con gái mà ngồi kế nhau, thế nào cũng nói chuyện, còn làm bạn với con trai lại càng dễ hơn. Chỉ có con trai là khó like u hơn, VN boy don't like to talk much, fải rà đúng đài, kiếm đúng ngườ hợp tính mới nói chuyện đc, but I am trying to change it, its really hard tho.

It seems the girls can make friends more easily. A conversation can be initiated as soon as two girls get together. It is even easier for them to make friends with boys. Vietnamese boys don't like to talk much, They have to be at the same "frequency" to find the guy who shares similar characteristics before a conversation can begin. I am trying to change it but it is really hard.

Matsui (1988) found that Chinese women saw themselves being treated at Chinese universities primarily as genderless intellectuals while the Japanese said they were forced to behave in a "feminine" way in Japanese society because of social pressures. Regarding their own experience, most participating Vietnamese students think that gender roles in the United States are not as clearly defined as in Vietnam because many of them, living away from home, have to perform chores that traditionally belong 
to the other gender. They also think the ill-defined roles definitely do not impact their general adaptation efforts. However, there remain mixed feelings about the relationship between education and gender. On the one hand, Vietnamese students of both genders, coming from a culture that customarily favors males over females in many aspects of development such as education, believe that it is not culturally desirable for women to have too much education. Even some of the female students prefer husbands who attain a higher level of education than their own. On the other hand, both genders agree that the level of education, as well as the selection of the field of study, should not be dependent on one's gender but rather on one's ability and financial resources. Ngọc expressed her views:

Em có nghĩ nhu vậy, học cao quá thì khó kiếm được bạn trai tương xứng. Chiếu về xã hội Việt Nam thì sẽ khó kiếm được chồng. Nhung mà nếu chuyện đó xãy ra với em thì em vẫn chọn là mình sẽ hoc. Không biết tại sao... Em chon major [Business] là vì em thích chú không phải vì em là con gái.

I did think that girls with a lot of education will face a hard time searching for boyfriends who are comparable. In Vietnam, it is difficult for them to get married. But if that is what happens to me then I'd rather study. I don't know why... I choose my major [Business] because I like it, not because I am a girl.

While Dung remained ambivalent:

Địa vị trong xã hội thì nếu mình có khả năng thì mình vẫn tranh đua, ở Việt Nam và ngay cả ở Mỹ. Còn nói về vấn đề bằng cấp thì em cũng không biết vì chưa nghĩ đến vấn đề lập gia đình... Em cảm thấy phụ nư vẫn còn cần dựa vào một người chồng giõi giang hơn mình nên người ta ura nói học cao quá nhiều khi không kiếm được chồng. Em nghĩ ở Mỹ thì vấn đề này nhẹ hơn.

Respected positions in the society, either in Vietnam or in the US, are available to those who are able. I don't know yet which educational levels [to attain] because I have not thought about getting married... I think a woman still needs to depend on a husband who is better than her. That is why people said a girl with too much education would have a hard time searching for a husband. I think in the US, this issue is not that serious.

\section{Vietnamese American Community}

Despite their awareness of the anti-Vietnam atmosphere within the Vietnamese American community, many of the Vietnamese international students did not realize the intensity of such negative feelings and the depth of such hostility before. They soon found themselves caught in the middle of an on-going struggle between the Vietnamese American community and the current government of Vietnam. While some were told by their relatives not to identify themselves as international students from Vietnam for fear of being labeled as communist by the community, others have anti-communist relatives who do not hesitate to openly and harshly criticize Vietnam even in the students' presence. 
The situation becomes more stressful since many of them are perceived as rich children whose parents must have been corrupted communist officials. Dung described her experience and feelings:

Chú ấy là em của cô chủ nhà. Chú ấy đến chơi và nói em là con của cán bộ, của ông lớn được đi du hoc thì chắc là phải giàu lắm. Rồi khi đi về thì chú ấy nói "Chào cháu Bác Hồ"... Stress vì chuyện đó thì em không stress nhung em không dám tiếp xúc với nhũng người nhu vậy nũa. Em hiểu là khi họ sang đây thì ho cũng gặp nhiều khó khăn nên ho có thành kiến đối với tụi em. Nhung em nghĩ dù sao ho cũng nên thay đổi các thành kiến đó đi.

He is my landlord' brother. He came to visit and said that I must be the daughter of some cadre or some VIP and must be very rich to afford the overseas study. Before he left, he often said to me, "Goodbye to Uncle Ho's niece"... I am not stressed because of him but I dare not meet with such people again. I understand that these people faced hardship when they first came here and they developed some kind of prejudices against people like me. But I think they should change their attitude.

Even though these international Vietnamese students never claimed to be communist nor advocated for communism, many are frustrated by what they perceive as anti-Vietnam propaganda broadcasted in the Vietnamese-language radio and TV stations operated by members of the community. Thuận explained,

Nhìu khi nghe người ở bên đây (nguời Việt và ko phải người Việt Nam) mình mới ngớ người ra, nghe chuyện nc của mình như là ở đâu đó.

Many times, listening to people here [both Vietnamese and non-Vietnamese] I was quite astonished, I was not sure if those were stories about my country that I knew or of somewhere else.

This was particularly true during the annual commemoration of the loss of South Vietnam at the end of each April. To several of these students, the information is incompatible with and contradictory to their experience in Vietnam. The majority of them, therefore, do not feel connected to the Vietnamese American community because of its hostile political expressions and activities, particularly the anti-Vietnam sentiments of some of its members. Many students cope by attempting to stay neutral and to focus on their studies. Others remain silent and avoid confrontational discussions with their anticommunist acquaintances. Uyễn shared her feelings about the day marking the loss of South Vietnam:

Đi dọc nhũng con đường mang tên Mỹ, nhũng chiếc cò̀ vàng 3 sọc đỏ gì đó cú phấp phới bay, lá cò mà tôi chỉ biết sụ tồn tại của nó cách đây it lâu, bật radio có cố gắng cũng khó tránh khỏi nhũng phần bàn luận về cái ngày này, nhũng bàn luận theo cách mà họ nghĩ, chư không phải theo cách mà người khác, hay ít ra là tôi, đang suy nghĩ... tôi thu hẹp mình hơn!... Tôi không phải là một người tôn thờ 
tất cả nhũng gì đang xãy ra ở đất nước mình, nhung cũng không đồng ý với nhũng gì người ta nói sai về đất nước. Nghe buồn và đau lắm.

Walking along the streets with American names, I saw the flags with 3 red stripes on the yellow background whose origin I just recently learned. Listening to the [Vietnamese language] radio I could not escape the commentaries of that day [the fall of Saigon]. These were commentaries that did not reflect what others thought, at least what I thought... I tried to make myself smaller!... I am not one who irrationally worships everything that is happening in Vietnam. But I don't agree either with the fabrications others say about my country. It is depressing and very hurtful.

Ngọc also wrote about that day:

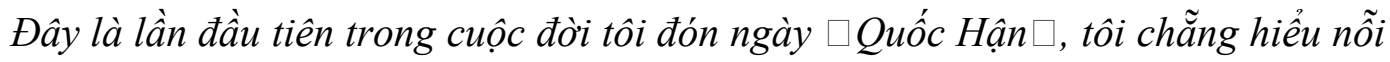
tại sao nguời Việt Nam ở đây lại đặt một cái tên nhu vậy cho cái ngày mà lẽ ra, ở đất nước tôi, ngày này mọi người ăn mùng phấn khởi. Có lẽ đó là một trong nhũng điểm khác biệt rất lớn, và cũng là một cái gì đó khiến cho tôi khong được thoãi mái lắm.

This is the first time that I greet the day of "National Shame." I can't fathom how the Vietnamese here can name as such to such a joyful day. In my country, this is a day of celebration and happiness. Perhaps this is one of the greatest differences, and also a reason why I don't feel comfortable.

Although the students seem to adjust generally well with the new educational settings, most dominant and serious adaptation problems include a wide range of issues related to language and communication, cultural awareness, and the feelings of isolation and loneliness. While only a few minor gender-based adaptation issues surfaced during the study, the financial problem is an incessant concern with these students. Despite the absence so far of any consequential effects, the politics of the Vietnamese American community has significantly, though subtly, impacted these international students whose typical adaptation strategy seems to be passive avoidance.

\section{Conclusion}

The overall experiences of the Vietnamese international students to the California college environment can be summarized from the large amount of data collected that illustrate some of their most impacted and lasting adaptation themes. Besides adjustment issues common among the general international student population, those experienced by international Vietnamese students are apparently influenced by their unique background and situation.

On the one hand, these students have obviously been able to achieve and maintain outstanding academic success, at least with the community colleges' lower division courses, despite their frequent struggle with the English language. Positive experiences with educational practices such as classroom participation, group study, and counseling, 
together with a balanced emphasis in both English grammar and oral skills in their high school years previously in Vietnam, would most likely have improved their adaptation efforts. On the other hand, they have encountered overwhelming difficulties in their desire and efforts to interact with American classmates.

This study found no major gender-based differences in the students' adaptation despite the residual effect they carried over from their awareness of some gender-based limitations experienced in Vietnam. The lack of cultural awareness and the feeling of isolation and loneliness were two main issues that cause severe adaptation problems for these students. To a large extent, due to the cultural and language diversity of the on-and off-campus environment, the impact of these main issues has been somewhat reduced. Finally, it was found that the political difference between the Vietnamese international students and the Vietnamese American community does exist and is a serious impediment to the students' adaptation process. However, it does not appear to have adversely affected the students' academic performance.

\section{Implications}

The findings of this study have several implications for the education and in particular successful adaptation of international Vietnamese students, and other international students in general.

\section{Skills in Oral English}

The problem of low proficiency in oral English calls for a review of the Vietnamese high school's foreign language curriculum that should emphasize a balance between grammar and oral skills. This should be in addition to establishing professional development programs to improve the oral skills of Vietnamese teachers who teach English. This problem also brings attention to the need for more effective and comprehensive oral English training programs for foreign students in American colleges, at least during their freshman years.

\section{Communication}

This issue brings forth the need to improve the cultural and language aspects in the orientation activities offered by the college's international student office to first year international students. Most often, these orientation sessions emphasize the academic and legal aspects of the student's sojourn and tend to neglect the cultural characteristics of the new environment these students will face. Unlike that of the four-year universities, community colleges' diverse and dynamic environment requires even more the need for better communication. At minimum, these communication issues deserve to be presented

as a topic in professional development programs to help the college's faculty and staff to become aware of the potential cultural discords. 


\section{Social Contacts}

The issues of social contact suggest the need for a more thoughtful approach in helping American and international students interact and form friendships. This will offer the former some cross-cultural experience and, at the same time, facilitate the latter's adaptation. American students in the study abroad program or in foreign language courses, who tend to appreciate other cultures and languages, could be selected and encouraged to interact with the international students, via student clubs or other services, to lessen the culture shock and to ensure a higher rate of interaction and integration of both populations. The socialization problems also imply needed cooperation between the college's international student office and other instructional and student services to increase the awareness of cross-cultural issues.

\section{Educational Concerns}

This issue calls for Vietnam's Ministry of Education and Training (MOET) to review the budget allocation for and to reform the pedagogical practices at both the secondary and post-secondary levels to help close the gap between the American and Vietnamese educational systems. Vietnam should, without trying to duplicate the entire American educational model, learn from the strengths and weaknesses of the American and other educational systems to improve its own. California community colleges, specifically due to their growing population of international students, should also increase their recruitment and training of bilingual, culturally sensitive and skilled counselors to better serve the international student population in general, and those from Vietnam in particular. Unlike their counterparts in the four-year university who often focus primarily on the academic aspects, two-year college counselors tend to address a wide range of academic, career, and personal issues that are unfamiliar and often unsettling to these international students.

\section{Financial Concerns}

The financial concerns of the Vietnamese international students bring attention to the need for Vietnam's MOET to review and modify its approach and policy regarding the development and disbursement of scholarships and other financial assistance to prospective international students. To help alleviate the students' financial hardship, American colleges also need to reconsider and expand their scholarship criteria to facilitate the international students' eligibility.

\section{Gender-Based Differences}

This issue brings forth fundamental and lingering questions regarding Vietnam's official policies and practices regarding the equitable and appropriate employment opportunities for students, both male and female, who return after their overseas study to help rebuild the country. This issue though complicated and requiring gradual and fundamental changes must be addressed and reassessed for the benefits of Vietnam's future generations. 


\section{Political Conflicts}

The Vietnamese embassy and its consulates need to understand and be more sympathetic to their students' difficult situations living in the midst of the anti-Vietnam, anticommunist atmosphere created by some members of the Vietnamese American community. Their staff should prepare to assist the Vietnamese international students and meet their needs that are not provided by the community.

\section{Suggestions for Further Study}

The findings of this study also point to the need for additional research in this area. The following are suggestions for further study.

\section{A Less Culturally Diverse Environment}

As discussed above, several students reported their unsuccessful integration into the mainstream. In that context, however, many also implied the positive and helpful effect of the high level of ethnic diversity in southern California. That implication offers a potential research focus on a comparative case study involving Vietnamese international students in a less culturally diverse environment, such as a state within the Midwest or within a community where Vietnamese speakers or members of other Asian populations are not as numerous as that in southern California. Focus can be placed on the nature of similar adaptation challenges or additional ones such as the issue of racism and the subsequent adaptation strategies.

\section{International Students and Their American Classmates}

One of the principal difficulties facing many Vietnamese students in this study was their inability to socialize with their American classmates. Due to logistic constraints and the narrow focus of this study, this issue was not explored and pursued. Also, this study only considers the contact between the two groups from the Vietnamese international students' perspectives but not that of their American classmates. An examination to understand the hosts' points of view will certainly add clarity and depth to the understanding of the interaction between the Vietnamese international students and the American college environment.

\section{International Students Returning to Vietnam}

Several students reported changes in their thinking, behavior, and way of life during their return to Vietnam to visit their family after a period of time living in the United States Ashwill (2001) reported:

Not all are welcomed home with open arms and placed on the fast track to promotion and opportunity. Many encounter resentment because they are now better qualified and more highly educated than their superiors; others become objects of suspicion because they have studied in the United States. Still others 
find that good jobs are given to relatives of company managers or to party officials, regardless of qualifications (p.11).

A study of the readjustment of the returning Vietnamese international students will provide a complete portrait of their experience.

In conclusion, as presented above, through individual case studies of a small number of Vietnamese international students, this study provided detailed descriptions and careful analyses of their adaptation experiences to the California community college environment. In light of the absence of any recent or past research regarding the adaptation of international students from Vietnam, this study offered a first glimpse of the difficulties facing these students, and their adaptation strategies to survive in the United States and attain their educational goals. Its overall significance, however, goes beyond the mere account of these students' adaptation efforts as it provides essential data for the comprehensive understanding of many of the cultural, social, academic, and political underlying rationales behind such adaptation problems. This understanding, in turn, would contribute to the knowledge and improvements of both the Ministry of Education and Training of Vietnam and the American higher educational institutions in their preparations, guidance, and assistance provided to Vietnamese international students to facilitate their adaptation and to assist their academic success in the United States.

\section{References}

American Association of Community and Junior Colleges (AACJC). (1998). Public policy agenda. Washington, D.C.

Ashwill, M. (2001). Looking to the west. International Educator 10(2), 6-11.

Barakat, H. A. (1988). A study of the problems facing foreign students attending Michigan State. Unpublished doctoral dissertation. Michigan State University, Ann Arbor.

Bleichmar, A. P. (1998). Cross-cultural training for foreign students in the context of the international student office. Unpublished doctoral dissertation. Massachusetts School of Professional Psychology, West Roxbury.

Bogdan, R. C., \& Biklen, S. K. (1998). Qualitative research for education: An introduction to theory and methods. Boston: Allyn and Bacon.

Borton, J. (2002). Vietnam's long road to learning. Asia Times Online. Retrieved November $29^{\text {th }} 2007$ from http://www.internationalreports.net/asiapacific/vietnam/2002/theroad.html.

Creswell, J. W. (1998). Qualitative inquiry and research design: Choosing among five traditions. Thousand Oaks, CA: Sage. 
Dalili, F. (1982a). Foreign students in institutions of higher education in the U.S. (ERIC Document Reproduction Service No. ED225498).

Dalili, F. (1982b). Roles and responsibilities of international student advisors and counselors in the United States (ERIC Document Reproduction Service No. ED226658.)

Do, M. (1986). Việt Nam máu lưa quê huơng tôi, Hồi ký chính trị. (Vietnam, my country of blood and fire. A political memoir). Fountain Valley, CA: Van Hoc.

Duong, T. T. (2002), Suy nghĩ về văn hóa giáo dục Việt Nam. (Some thoughts on the cultural education of Vietnam). Ho Chi Minh City, Vietnam: Nha Xuat ban Tre.

Education in Asian Civilizations: c.700 to the Eve of Western Influence. Encyclopedia Britannica [On-line]. Retrieved June 2, 2003 from http://www.britannica.com/eb/article?eu=108332.

Eid, M. T., \& Jordan-Domschot, T. (1989). Needs assessment of international students at Eastern Oregon State College. (ERIC Document Reproduction Service No. ED 326098).

Ellis, J. (1993). Japanese students abroad: Relating language ability in class and in the community. Thought Currents in English Literature, 66, 45-82.

Fatima, N. (2001, April). International female graduate students' perceptions of their adjustment experiences and coping strategies at an urban research university. Paper presented at the Annual Meeting of the American Educational Research Association, Seattle, WA.

Fels, M. D. (1994). Imagining America: A study of assumptions and expectations among English as a Second Language students from Japan. Paper presented at the Annual Meeting of the Speech Communication Association, New Orleans, LA.

Feng, J. (1991). The adaptation of students from the People's Republic of China to an American academic culture. (ERIC Document Reproduction Service No. ED329833).

Foreign students' countries of origins (2005, August 26). The Chronicle of Higher Education, p. 19.

Gribbons, B., \& Dixon, P. S. (2001). College of the Canyons International Students Program student questionnaire, Fall 2000. (ERIC Document Reproduction Service No. ED454927). 
Journal of Southeast Asian American Education and Advancement, Vol. 2 [2007], Iss. 1, Art. 1

Huebner, L. A., \& Corazzini, J. G. (1978). Ecomapping: A dynamic model for intentional campus design. In L. Huebner (1989), Interaction of student and campus (pp. 165-207). San Francisco: Jossey-Bass Publishers.

Igasaki, P \& Niedzwiecki, M. (2004). Aging among Southeast Asian Americans in California: Assessing strengths and challenges, strategizing for the future. Washington, DC: Southeast Asia Resource Action Center. Available: http://www.searac.org/aging-seaamer-fin.pdf

Kim, B., Brenner, B., Liang, C., \& Asay, P. (2003). A qualitative study of adaptation experience of 1.5-generation Asian Americans. Cultural Diversity \& Ethnic Minority Psychology, 9(2), 156-170.

Kinoshita, A., \& Bowman, R. L. (1998). Anxiety levels among Japanese students on American campuses: Implications for academic advisors. NACADA Journal, 18(1), 27-34.

Lacina, J. (2002). Preparing international students for a successful social experience in higher education. New Directions for Higher Education, 117 (Spring), 21-28.

Lee, W., \& Mixson, R. (1995). Asian and Caucasian client perceptions of the effectiveness of counseling. Journal of Multicultural Counseling and Development, 23(1), 48-56.

Martelle, S. \& Tran, M. (2000, April 28). A generation removed: Lessons and legacies/ 25 years after Vietnam. Los Angeles Times. Orange County edition, p. 1.

Matsui, M. (1988). Comparative study of female overseas students from Japan and the People's Republic of China at an American university. (ERIC Document Reproduction Service No. ED322071).

Miles, M. B. \& Huberman, A. M. (1994). An expanded sourcebook: Qualitative data analysis. Thousand Oaks, CA: Sage.

NAFSA (2002). Fact sheet [On-line]. Available: http://opendoors.iienetwork. org/?p=25185

Nguyen, K. (1998). Alexandre De Rhodes, ngườ đầu tiên vận động Pháp chiếm Việt Nam, và chũ quốc ngũ. (Alexandre De Rhodes, who first campaigned France to colonize Vietnam, and the romanization of Vietnamese language). Garden Grove, CA: Giao Diem.

Paul, S. (1980). Understanding student-environment interaction. In W. H. Morrill, J. C. Hurst, E.R. Oetting, et al. Dimensions of interventions for student development (pp. 58-81). New York: John Wiley and Sons - Interscience. 
Pham, H. M. (1998). Vietnam's education: The current position and future prospects. Ho Chi Minh City, Vietnam: The Gioi Publishers.

Pham, V. H. (2002). Beyond and before boatpeople: Vietnamese American history before 1975. Unpublished doctoral dissertation, Cornell University, Ithaca, NY.

Porter, J. W. (1962). The development of an inventory to determine the problems of foreign students. (Doctoral dissertation, Michigan State University, 1962) Dissertation Abstracts International, 23/10A, p. 378.

Porter, J. W. (1977). Michigan International Student Inventory (Rev. ed.). East Lansing: Michigan State University.

Seidman, I. (1998). Interviewing as qualitative research. New York: Teachers College Press.

Siegel, C. (1991). Counseling international students: A clinician's comments. Counseling Psychologist, 19(1), 72-75.

Stake, R. (1995). The art of case study research. Thousand Oaks, CA: Sage.

Stevens, K., \& Phillips, J. (1990). Vietnamese students at Drexel University: An explorative field study. (ERIC Document Reproduction Service No. ED334893).

Sun, W., \& Chen, G. (1997, March). Dimensions of difficulties Mainland Chinese students encounter in the United States. Paper presented at the International Conference in Cross-Cultural Communication, Tempe, AZ.

Wilson, S. R. (1996). East Asian international students' stressors and coping behaviors (Chinese, Japanese, Taiwanese, Korean). Unpublished doctoral dissertation, Boston University, Boston.

Wu, X. (1993). Patterns of adjustment concerns and needs perceived by international students in a community college environment in Iowa. Unpublished doctoral dissertation, University of Iowa, Iowa City.

Yin, R. (2003). Case study research, design and methods. Thousand Oaks, CA: Sage.

Yook, E. (1995, April). Culture shock in the basic communication course: A case study of Malaysian students. Paper presented at the Annual Meeting of the Central States Communication Association, Indianapolis, IN.

Zimmermann, S. (1995). Perceptions of intercultural communication competence and international student adaptation to an American campus. Communication Education, 44(4), 321-335. 


\begin{abstract}
About the Author
Dr. Tam Huu Do has worked in the field of counseling since 1996 at Irvine Valley College. He is an academic advisor to the college's international student population and is also currently assisting historically disadvantaged students in the Extended Opportunities Programs and Services (EOPS). Originally from Vietnam, Dr. Do is the co-director of the California-based Giao-Diem Humanitarian Foundation which has conducted charity activities in Vietnam since 1991.
\end{abstract}




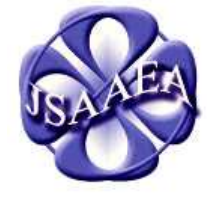

Volume 2

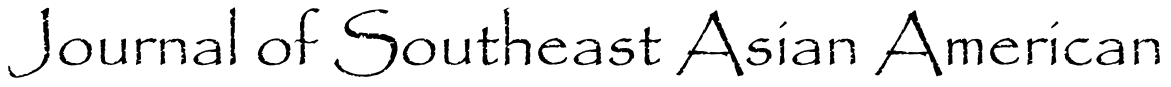

Education \& Advancement

\author{
WWW.JSAAEA.org \\ Editor \\ Dr. Wayne E. Wright \\ University of Texas, San Antonio \\ Associate Editors \\ Dr. Chhany Sak-Humphry \\ University of Hawaii \\ Dr. KimOanh Nguyen-Lam \\ California State University, Long Beach \\ Book Review Editor \\ Dr. Leslie Turpin \\ School for International Training \\ Creative Works Editor \\ Phouang Hamilton \\ Washington Office of Superintendent of Public Instruction \\ Special Advisor \\ Anne Frank \\ University of California, Irvine, Southeast Asian Archives

\section{Editorial Assistant} \\ Shereen Bhalla \\ University of Texas, San Antonio
}

A peer-reviewed

scholarly journal published by the

National Association

for the Education \&

Advancement of

Cambodian, Laotian,

and Vietnamese

Americans (NAFEA)

Comments and questions for the editorial staff may be directed to jsaaea@lists.sis.utsa.edu

\section{Editorial Review Board}

\author{
Dr. Carl L. Bankston III \\ Tulane University \\ Dr. Pollie Bith-Melander \\ San Jose State University \\ Dr. Phala Chea \\ Lowell Public Schools \\ Dr. George Chigas \\ University of Massachusetts, Lowell \\ Dr. Changming Duan \\ University of Missouri, Kansas City
}

\author{
Dr. Sophal Ear \\ Syracuse University \\ Dr. Nancy H. Hornberger \\ University of Pennsylvania \\ Dr. Samlong Inthaly \\ Minneapolis Public Schools \\ Dr. Peter Nien-Chu Kiang \\ University of Massachusetts, Boston \\ Dr. Kevin K. Kumashiro \\ University of Illinois, Chicago
}




\author{
Dr. Stacey Lee \\ University of Wisconsin, Madison \\ Dr. David Chanpannha Ley \\ Montgomery County Public Schools \\ Dr. Sue Needham \\ California State University, Dominguez Hills \\ Dr. Bic Ngo \\ University of Wisconsin-Madison \\ Dr. Max Niedzwiecki \\ Rights Working Group \\ Dr. Leakhena Nou \\ California State University, Long Beach \\ Dr. Clara Park \\ California State University, Northridge \\ Dr. Mark Pfeifer \\ Texas A\&M University, Corpus Christi \\ Dr. Loan T. Phan \\ University of New Hampshire \\ Dr. Bounlieng Phommasouvanh \\ Minnesota Department of Education \\ Dr. Karen Quintiliani \\ California State University, Long Beach
}

Dr. Kalyani Rai

University of Wisconsin, Milwaukee

Dr. Fay Shin

California State University, Long Beach

Dr. Nancy J. Smith-Hefner

Boston University

Dr. Yer J. Thao

Portland State University

Dr. Myluong Tran

San Diego State University

Dr. Khatharya Um

University of California, Berkeley

Dr. Linda Trinh Vo

University of California, Irvine

Dr. Terrence G. Wiley

Arizona State University

Dr. Zha Blong Xiong

University of Minnesota

Dr. Kou Yang

California State University, Stanislaus

\title{
Doctoral Student \\ Editorial Review Board
}

\author{
Keo Chea \\ University of Pennsylvania \\ Vichet Chhuon \\ University of California, Santa Barbara \\ Loan Dao \\ University of California, Berkeley \\ Annie BichLoan Duong \\ San Joaquin County Office of Education \\ Ha Lam \\ Arizona State University \\ Ravy Lao \\ University of California, Santa Barbara \\ Vanna Som \\ Harvard University
}

\author{
Rassamichanh Souryasack \\ University of California, Santa Barbara \\ Giang Pham (Formerly Giang Tang) \\ University of Minnesota \\ Layheng Ting \\ State University of New York, Albany \\ Tinou Tran \\ University of Houston, Texas \\ Loan Tran \\ University of California, Santa Barbara \\ Phitsamay Sychitkokhong Uy \\ Harvard University \\ Yang Sao Xiong \\ University of California, Los Angeles
}

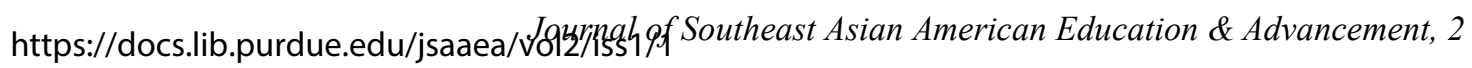

